\title{
Coronary artery surgery in women compared with men: analysis of coronary risk factors and in- hospital mortality in a single centre
}

\author{
M Barbir, F Lazem, C Ilsley, A Mitchell, A Khaghani, M Yacoub
}

\begin{abstract}
Objective-To determine differences in coronary risk factors between women and men and their relation to in-hospital mortality associated with coronary artery bypass grafting.
\end{abstract}

Design-Prospective observational study. Setting-A regional cardiothoracic centre. Patients-482 (362 (75\%) men and 120 (25\%) women) consecutive patients who had primary isolated coronary artery bypass grafting.

Results-The women were on average three years older than the men (63 $v 60$ years, $P<0.001)$. Women more frequently had hypertension (47\% v 33\%, $P<0.01)$, diabetes mellitus $(21 \% v 10 \%$, $\mathbf{P}<0.005)$, hypothyroidism (9\% v $2 \%, P$ $<0.003$ ), and a family history of premature coronary heart disease $(49 \% v 31 \%$, $P<0.0006)$. More of the men were cigarette smokers $(67 \% v 45 \%, P>0.00001)$. Many of the women and men had dyslipidaemia. Postmenopausal women had a higher concentration of serum total cholesterol than men of a comparable age, $(7.3 \mathrm{mmol} / 1$ v $6.5 \mathrm{mmol} / 1, P=0.0002)$. Although arterial grafts were often used in both sexes, they were more often used in men than in women $(91 \%, v 78 \%$ respectively, $P=0.0003)$. In-hospital mortality was $2 \cdot 1 \%(1.4 \%$ in men and $4 \cdot 2 \%$ in women, $P=0 \cdot 14)$. The estimated one year probability of survival in men who had survived 30 days was 0.99 with $95 \%$ confidence interval 0.98 to approximately 1 while that for women was 0.97 with $95 \%$ confidence interval 0.91 to approximately 1. Univariate analysis showed that preoperative history of diabetes mellitus was a predictor of mortality $(P=0.03)$.

Conclusion-There were differences in the incidence and type of risk factors in men and women who had coronary artery bypass grafting. Preoperative diabetes mellitus was a predictor of in-hospital mortality.

(Br Heart f 1994;71:408-412)

In the United Kingdom coronary heart disease is the leading cause of death in women over 65 years of age and a major contributor to mortality in younger women. ${ }^{1}$ Whereas the disease is less prevalent in premenopausal women than in men, its incidence increases rapidly after the menopause so that rates of coronary disease are almost equal in women and men over sixty. ${ }^{2}$

In 1991 in England and Wales 68479 women and 81611 men died of coronary heart disease. ${ }^{1}$ The latest data available from the World Health Organisation show that mortality from coronary heart disease in women is highest in Scotland (121/100 000) where it is almost double that in the United States $(67 / 100000) .^{3}$

At all ages the incidence of coronary artery disease in women has increased and its outcome seems worse than that in men suggesting a different type of disease ${ }^{4}$ and possibly a different set of risk factors. Most studies showed that the immediate and long-term prognosis in women is worse than that in men after myocardial infarction ${ }^{5-7}$ and after therapeutic interventions such as coronary balloon angioplasty. ${ }^{8}$ Coronary artery bypass grafting (CABG) remains the most commonly used form of myocardial revascularisation, however, there is perceived to be a possible bias against women in terms of the application of coronary angiography and CABG. This has been the subject of extensive debate. ${ }^{9}$ Coronary surgery is thought to carry higher operative mortality in women than in men..$^{10-17}$ This excess in mortality has been attributed to several factors including age, functional class, a smaller body, ${ }^{18}$ severity of coronary heart disease (CHD), and the technical difficulties of operating on women. ${ }^{1213}$ The relative incidence of coronary risk factors in women and men undergoing $\mathrm{CABG}$ and the possible influence on early mortality has not been adequately studied.

We have studied the differences in risk factors between men and women and their relation to hospital mortality associated with CABG.

\section{Patients and methods}

From 1 January 1991 to 31 May 1993 all patients admitted under one of two surgical teams at Harefield Hospital for primary CABG were included in the study. We did not include patients undergoing CABG incidental to heart valve replacement or repair, resection of ventricular aneurysm, or other surgical procedures. We studied 482 consecutive patients $(362(75 \%)$ men and $120(25 \%)$ women). To compare men and women we collected data on patient age; body mass index; body surface area; hypertension, diabetes mellitus, and hypothyroidism requiring 
therapy; peripheral vascular disease; previous myocardial infarction; family history of premature coronary artery disease; cigarette smoking; preoperative medications; preoperative fasting lipids and lipoproteins; type of graft (venous or arterial), and state at hospital discharge (alive or dead) and follow up. Inhospital mortality was defined as death occurring within 30 days of $\mathrm{CABG}$.

Preoperative fasting serum, total cholesterol, and triglyceride were analysed enzymatically, as was high density lipoprotein cholesterol after precipitation with heparinmanganese. The concentration of low density lipoprotein (LDL) cholesterol was calculated by the formula of Friedewald et al ${ }^{19}$ except in patients with triglyceride concentrations $4.5 \mathrm{mmol} / 1$ in whom LDL cholesterol was measured after ultracentrifugation of serum. ${ }^{20}$ Body surface area was calculated by the method of Dubois and Dubois ${ }^{21}$ :

$$
\sqrt{\frac{\text { height }(\mathrm{cm}) \times \text { weight }(\mathrm{kg})}{3600}}
$$

STATISTICAL ANALYSIS

We used the two sample $t$ test for independent variables and the $\chi^{2}$ test with Yates' correction as appropriate to compare differences

Table 1 Comparison of risk factors in women and men undergoing coronary artery bypass grafting (mean (SE) and percentages as appropriate)

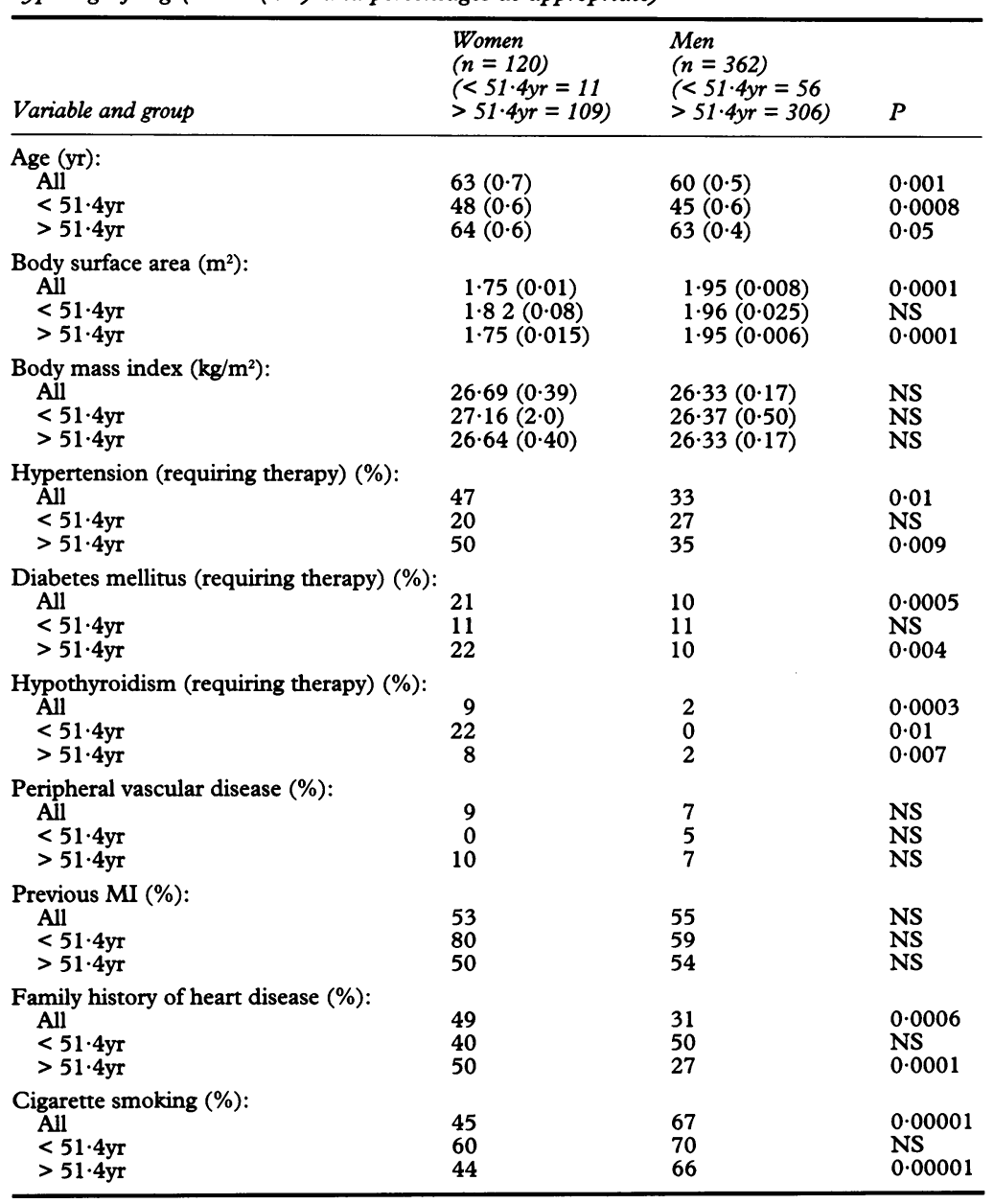

BMI, body mass index; CHD, coronary heart disease; MI, myocardial infarction. Smokers were currently smoking $>10$ cigarettes/day or had given up less than a year before. between groups. It is generally accepted that the average age of menopause is 51.4 years with a gaussian distribution ranging from 40 to 58 years. ${ }^{22}$ We compared men and women with and without stratification by age (below 51.4 years premenopausal and above 51.4 years postmenopausal) because not all women aged $<51.4$ years are premenopausal and not all those aged $>51.4$ years are postmenopausal.

The confidence intervals for the probability of survival were obtained from the observed proportions of male and female patients surviving to 30 days after operation. In view of the low mortality, it was appropriate to evaluate these directly from the underlying binomial distribution rather than to use a normal approximation and quote standard errors. ${ }^{23}$

Triglyceride values were log transformed (because of skewed distribution) before statistical analysis (table 3 shows untransformed values). In all analyses a difference of $P<$ 0.05 was regarded as statistically significant.

\section{Results}

Table 1 shows the prevalence of coronary risk factors. On average women were 3 years older than men $(63 v 60$ years, $\mathrm{P}<0.001)$ and the mean body mass index was slightly higher. Women more likely to have hypertension $(47 \%$ v 33\%, $\mathrm{P}<0.01)$, diabetes mellitus (21\% v 10\%, P < 0.005), hypothyroidism ( $9 \% v 2 \%, \mathrm{P}<0.0003)$, and a family history of premature coronary heart diseases $(49 \% v$ $31 \%, P<0.0006)$.

The incidence of preoperative myocardial infarction was high in women (53\%) and men $(55 \%)$ and similar percentages of women (9\%) and men $(7 \%)$ had peripheral vascular disease.

Though a similar proportion of women

Table 2 Comparison of preoperative class of medication in women and men (results all expressed as percentages)

\begin{tabular}{|c|c|c|c|}
\hline $\begin{array}{l}\text { Variables } \\
\text { and } \\
\text { Group }\end{array}$ & $\begin{array}{l}\text { Women } \\
(n=120) \\
(<51.4 y r=11 \\
>51.4 y r=109)\end{array}$ & $\begin{array}{l}\text { Men } \\
(n=362) \\
(<51 \cdot 4 y r=56 \\
>51 \cdot 4 y r=306)\end{array}$ & $P$ \\
\hline $\begin{array}{l}\beta \text { blockers: } \\
\text { All } \\
<51 \cdot 4 \mathrm{yr} \\
>51 \cdot 4 \mathrm{yr}\end{array}$ & $\begin{array}{l}58 \\
50 \\
59\end{array}$ & $\begin{array}{l}59 \\
59 \\
60\end{array}$ & $\begin{array}{l}\text { NS } \\
\text { NS } \\
\text { NS }\end{array}$ \\
\hline $\begin{array}{l}\text { Diuretics: } \\
\text { All } \\
<51 \cdot 4 \mathrm{yr} \\
>51 \cdot 4 \mathrm{yr}\end{array}$ & $\begin{array}{l}34 \\
30 \\
35\end{array}$ & $\begin{array}{l}16 \\
14 \\
16\end{array}$ & $\begin{array}{l}0.0001 \\
\text { NS } \\
0.0001\end{array}$ \\
\hline $\begin{array}{l}\text { Lipid lowering } \\
\text { drugs: } \\
\text { All } \\
<51 \cdot 4 \mathrm{yr} \\
>51 \cdot 4 \mathrm{yr}\end{array}$ & $\begin{array}{l}17 \\
20 \\
17\end{array}$ & $\begin{array}{r}7 \\
11 \\
6\end{array}$ & $\begin{array}{l}0.002 \\
\mathrm{NS} \\
0.002\end{array}$ \\
\hline $\begin{array}{l}\text { ACE inhibitors: } \\
\text { All } \\
<51.4 \mathrm{yr} \\
>51.4 \mathrm{yr}\end{array}$ & $\begin{array}{l}11 \\
20 \\
10\end{array}$ & $\begin{array}{l}8 \\
7 \\
9\end{array}$ & $\begin{array}{l}\text { NS } \\
\text { NS } \\
\text { NS }\end{array}$ \\
\hline $\begin{array}{l}\text { Calcium } \\
\text { antagonist: } \\
\text { All } \\
<51 \cdot 4 \mathrm{yr} \\
>51 \cdot 4 \mathrm{yr}\end{array}$ & $\begin{array}{l}52 \\
50 \\
57\end{array}$ & $\begin{array}{l}49 \\
47 \\
51\end{array}$ & $\begin{array}{l}\text { NS } \\
\text { NS } \\
\text { NS }\end{array}$ \\
\hline $\begin{array}{l}\text { Oral nitrates: } \\
\text { All } \\
\quad<51 \cdot 4 \mathrm{yr} \\
>51 \cdot 4 \mathrm{yr}\end{array}$ & $\begin{array}{l}78 \\
90 \\
77\end{array}$ & $\begin{array}{l}82 \\
77 \\
83\end{array}$ & $\begin{array}{l}\text { NS } \\
\text { NS } \\
\text { NS }\end{array}$ \\
\hline
\end{tabular}


Table 3 Preoperative fasting serum lipids and lipoproteins value (mean (SE))

\begin{tabular}{llll}
\hline $\begin{array}{l}\text { Variable } \\
\text { and } \\
\text { group }\end{array}$ & $\begin{array}{l}\text { Women } \\
(n=120) \\
(<51 \cdot 4 y r=11 \\
>51 \cdot 5 y r=109)\end{array}$ & $\begin{array}{l}\text { Men } \\
(n=362) \\
(<51 \cdot 4 y r=56\end{array}$ & \\
$>51 \cdot 4 y r=306)$ & $P$
\end{tabular}

Table 4 Comparison of venous and arterial grafts in women and men (mean (SE))

\begin{tabular}{|c|c|c|c|}
\hline $\begin{array}{l}\text { Variable } \\
\text { and } \\
\text { group }\end{array}$ & $\begin{array}{l}\text { Women } \\
(n=120) \\
(<51 \cdot 4 y r=11 \\
>51.4 y r=109)\end{array}$ & $\begin{array}{l}\text { Men } \\
(n=362) \\
(<51 \cdot 4 y r=56 \\
>51 \cdot 4 y r=306)\end{array}$ & $P$ \\
\hline $\begin{array}{l}\text { Number of } \\
\text { venous grafts: } \\
\text { All } \\
<51 \cdot 4 \mathrm{yr} \\
>51 \cdot 4 \mathrm{yr}\end{array}$ & $\begin{array}{l}2 \cdot 4(0 \cdot 08) \\
2 \cdot 4(0 \cdot 15) \\
2 \cdot 5(0 \cdot 1)\end{array}$ & $\begin{array}{l}2 \cdot 5(0 \cdot 04) \\
2 \cdot 1(0 \cdot 13) \\
2 \cdot 5(0.05)\end{array}$ & $\begin{array}{l}\text { NS } \\
\text { NS } \\
\text { NS }\end{array}$ \\
\hline $\begin{array}{l}\text { Number of } \\
\text { arterial grafts: } \\
\text { All } \\
<51 \cdot 4 \mathrm{yr} \\
>51 \cdot 4 \mathrm{yr}\end{array}$ & $\begin{array}{l}0.8(0.04) \\
0.8(0.12) \\
0.8(0.05)\end{array}$ & $\begin{array}{l}1.0(0.03) \\
1.14(0.06) \\
0.93(0.03)\end{array}$ & $\begin{array}{l}0.0003 \\
0.032 \\
0.002\end{array}$ \\
\hline
\end{tabular}

$(60 \%)$ and men $(70 \%)$ below the age of 51.4 years were cigarette smokers; men aged $>51.4$ years were more likely than women of the same age to be cigarette smokers $(66 \% v$ $44 \%, \mathrm{P}<0.00001$ ).

Table 2 shows preoperative medications in women and men. Women were more likely to be taking diuretics $(34 \% v 16 \%, \mathrm{P}=0.0001)$ and lipid lowering drugs $(17 \%$ v $6 \%, \mathrm{P}=$ $0.0002)$ than men of the same age; however, there was no difference in proportion of women and men on $\beta$ blockers, ACE inhibitors, calcium antagonists, and oral

Table 5 Data on operative deaths

\begin{tabular}{|c|c|c|c|c|c|c|c|c|}
\hline $\begin{array}{l}\text { Case } \\
\text { No }\end{array}$ & Sex & $\begin{array}{l}\text { Age } \\
(y r)\end{array}$ & $\begin{array}{l}V \\
\text { Preop } \\
\text { state }\end{array}$ & $\begin{array}{l}\text { Vessels } \\
\text { diseased } \\
(n)\end{array}$ & $L V E F$ & $\begin{array}{l}\text { Cause } \\
\text { of } \\
\text { death }\end{array}$ & $\begin{array}{l}\text { Time } \\
\text { of } \\
\text { death }\end{array}$ & $\begin{array}{l}\text { Priority } \\
\text { of surgery }\end{array}$ \\
\hline 1 & $\mathrm{~F}$ & 53 & PI,UA & 3 & 45 & AMI & 5 days & Emergency \\
\hline 2 & $\mathrm{~F}$ & 72 & UA & $3+\mathrm{LM}$ & 50 & $\mathrm{PE}$ & 12 days & Emergency \\
\hline 3 & $\mathrm{~F}$ & 51 & PI,UA & 3 & 45 & $\mathrm{HF}$ & 1 day & Emergency \\
\hline 4 & $\mathrm{~F}$ & 65 & UÁ,COPD & 3 & 45 & $\mathrm{HF}$ & $\begin{array}{l}\text { Same day } \\
\text { ITU }\end{array}$ & Elective \\
\hline 5 & $\mathrm{~F}$ & 61 & SA, & 3 & 40 & $\mathrm{HF}$ & $\begin{array}{l}\text { Same day } \\
\text { ITU }\end{array}$ & Elective \\
\hline 6 & $M$ & 69 & PI,UA & 3 & 20 & $\mathrm{HF}$ & 1 day & Emergency \\
\hline 7 & $M$ & 63 & PI,UA & 3 & 18 & $\mathrm{HF}$ & 22 days & Emergency \\
\hline 8 & M & 58 & SA, & 3 & 50 & $\mathrm{HF}$ & 2 days & Elective \\
\hline 9 & M & 67 & $\mathrm{SA}$, & 3 & 40 & $\mathrm{HF}$ & 15 days & Elective \\
\hline 10 & $M$ & 72 & PI,UA & 3 & 20 & $\mathrm{HF}+\mathrm{RF}$ & 3 days & Elective \\
\hline
\end{tabular}

AMI, acute myocardial infarction; COPD, chronic obstructive pulmonary disease; HF, heart failure; PI, postmyocardial infarction; PE, pulmonary embolism; RF, renal failure; SA, stable angina; UA, unstable angina; LM, left main stem. nitrates. Women over 51.4 years (postmenopausal) had a higher concentration of serum total cholesterol than men of a similar age (table 3$)(7.3 \mathrm{mmol} / 1$ v $6.5 \mathrm{mmol} / 1, \mathrm{P}=$ $0 \cdot 0002)$. There was no significant difference in serum triglycerides, HDL cholesterol, and LDL cholesterol (table 3).

Though most women and men in this study received arterial grafts, men were more likely to receive an arterial graft $(78 \% v 91 \%, \mathrm{P}=$ $0.0003)$. Overall those receiving arterial grafts were younger $(60.1$ years $v 64.9$ years, $\mathrm{P}=$ $0.00001)(59.4$ years $v 65.8$ years, $P=$ 0.00001 in men and 62.6 years $v 63.7$ years, $P=0.48$, in women). Fewer patients with diabetes mellitus (77\%) received arterial grafts than those without $(87 \%)(P=0.044)$. Comparable figures in women were $62.5 \%$ and $79.8 \%(P=0.048)$ and in men they were $86.5 \%$ and $88.7 \%(P>0 \cdot 1)$. Table 4 compares the use of arterial and venous grafts in women and men.

\section{OPERATIVE MORTALITY}

There were $10(2 \cdot 1 \%)$ early deaths (within 30 days of CABG). Mortality for men was $1 \cdot 4 \%$ $(5 / 362)$ and for women $4 \cdot 2 \%(5 / 120)(P=$ $0 \cdot 14)$. Table 5 shows detailed characteristics of the 10 patients who died: these patients had severe three vessel disease, in addition $70 \%$ had unstable angina and $50 \%$ were admitted for emergency surgery. There were three late deaths: two women and one man died during the follow up of 1 year. The estimated probability of survival for 30 days in men was 0.99 (95\% CI 0.97 to 0.99 ) while that for women was 0.96 (95\% CI 0.90 to 0.99$)$.

The estimated 1 year probability of survival for men who survived 30 days was 0.99 (95\% CI 0.98 to approximately 1) while that for women was 0.97 (95\% CI 0.91 to approximately 1 ).

In univariate analysis a preoperative history of diabetes mellitus was found to be a significant predictor of in-hospital mortality $(\mathrm{p}=$ $0.03)$. None of the other variables including age, sex, body surface area, and hypertension showed statistically significant effects on mortality.

\section{Discussion}

Differences between men and women in potential risk factors for severe coronary artery disease requiring $\mathrm{CABG}$ were identified in this study. Women were significantly older than men and more frequently had hypertension, diabetes mellitus, hypercholesterolaemia, hypothyroidism, and a family history of premature coronary artery disease. Studies suggest that hypertension is a major risk factor for coronary heart disease in women. ${ }^{24} 25 \mathrm{We}$ found that hypertension was more prevalent among postmenopausal women than among men of the same age. Staessen et al reported a fourfold higher prevalence of hypertension in postmenopausal women than in premenopausal women $(40 \% v 10 \%, \mathrm{P}<0.001) .{ }^{26}$ The reason for this difference remains unexplained. Prospective studies confirmed that 
diabetes mellitus is an independent risk factor for coronary heart disease in women. ${ }^{27}{ }^{28}$ Our study and that of Kennel and McGee suggest that the attributable risk of diabetes for coronary artery disease is higher in women than in men. ${ }^{27}$ In addition, we found that diabetes mellitus is a predictor of in-hospital mortality after CABG. Similar findings were reported by Fietsam et al. ${ }^{29}$ The importance of diabetes as a risk factor may be related to the accompanying atherosclerosis and impairment of the autonomic nervous system. Autonomic dysfunction and neuropathy in diabetic patients cause a high incidence of silent myocardial infarction and have a considerable impact on changes in blood pressure and heart rate during anaesthesia. ${ }^{3031}$ Diabetic patients also require more intraoperative vasopressors and inotropes to support the circulation ${ }^{30}$ and have a high risk of respiratory failure and arrhythmias after CABG. ${ }^{29}$ Identification and appropriate management of these complications could reduce the risk in this subset of patients.

In this study a high proportion of women and men had raised concentrations of fasting serum total cholesterol, triglycerides, and LDL cholesterol. Although more women were treated with lipid lowering drugs, their total fasting serum cholesterol was significantly higher than that of men. Several epidemiological studies confirm that raised concentrations of cholesterol are a risk factor for coronary artery disease in women. ${ }^{24} 3132$ Data from the Framingham Study demonstrate a direct relation between total cholesterol concentration and annual rate of coronary artery disease. ${ }^{32}$ Women with a total cholesterol concentration above $6.85 \mathrm{mmol} / \mathrm{l}$ had an approximately twofold higher risk of coronary artery disease than women with a cholesterol concentration of $\leqslant 5.3 \mathrm{mmol} / 1$. Other studies suggest that triglyceride concentrations are also an important risk factor in women. ${ }^{33} 34$

Though most secondary prevention trials of regression of coronary artery disease have included few women the studies of Ornish et $a l^{35}$ and Kane $e t a l^{36}$ suggest that the anticipated benefit of lipid lowering drugs with diet in the treatment of atherosclerosis applies to women as well as to men and, they suggest that the ability to undergo coronary atherosclerotic regression is greater in women.

We found no difference in in-hospital mortality in women and men below the age of 51.4 years $(0 \%)$. Mortality in women above the age of $51.4 \%$ (postmenopausal) was $4.2 \%$ and in men it was $1.4 \%(P=0 \cdot 14)$. The mortality in women resembled that reported by Khan et al (4.6\%) and O'Connor et al $(7 \cdot 1 \%) .{ }^{15} 37$

Our data did not show any significant effect of body surface area, body mass index, or age on in-hospital mortality. Loop et al, however, suggested that body surface area was the strongest predictor of operative risk, even when the model was adjusted for sex. ${ }^{13}$

Most patients in our study received arterial grafts and among women their use was especially higher $78 \%$ compared with $64.8 \%$ reported in a recent study. ${ }^{37}$ The lower fre- quency of arterial grafting among women remains unexplained. ${ }^{15} 37$ In our study the lower frequency of internal mammary artery grafting in women was partly the result of the higher proportion of women with diabetes mellitus. In addition other factors such as the smaller size and inadequate flow through the internal mammary artery in some patients may also be important. Internal mammary arterial grafts had more favourable intermediate and long-term patency rates than venous grafts. ${ }^{38-41}$ In addition, grafting of the internal mammary artery reduced late cardiac events and increased long-term survival. ${ }^{38}$

The analysis of predictors of mortality was limited because the univariate analysis lacked statistical power owing to the low number of deaths. Similarly, multivariate analysis could not be used because of the small number of events. Data on functional class, ventricular ejection fraction, and surgical technique (such as pump and ischaemic time) for women and men were not analysed in this study which focused on coronary risk factors.

In conclusion, risk factors for coronary artery disease were significantly more common in women undergoing CABG than in men. There was a slight but not statistically significant increase in hospital mortality in women compared with men. Preoperative diabetes mellitus seemed to be a significant predictor of in hospital mortality after CABG.

Further studies are needed to confirm our findings and establish their effect on mortality and the effect of risk factor modification on outcome. We hope that such studies will improve the application and results of CABG in women.

We thank Mrs Sheila Neves for secretarial assistance and Dr Derek Robinson for statistical analysis.

1 Office of population censuses and surveys monitor 1992, DH2 92/2.

2 Lerner DJ, Kannel WB. Patterns of coronary heart disease morbidity and mortality in the sexes: a 26-years followup of the Framingham population. Am Heart $f$ 1986;

3 Mulcahy $\mathrm{R}$, Mulcahy $\mathrm{H}$, Hickey $\mathrm{N}$. Is the coronary epidemic on the wane? British fournal of Cardiology 1993;1: 35-9.

4 Mautner SL, Lin F, Mautner GC, Roberts WC. Comparison in Women versus Men of Composition of Atherosclerotic Plaques in Native Coronary Arteries and in Saphenous Veins used as Aortocoronary Conduits. $\mathcal{F}$ Am Coll Cardiol 1993;21:1313-8.

5 Kannel WB, Sorlie P, McNamara PM. Prognosis after initial myocardial infarction: The Framingham Study. $A m$ f Cardiol 1979;44:53-9.

6 Tofler GH, Stone PH, Muller JE, Willich SN, Davis VG, Poole WK, et al. Effects of gender and race on prognosis after myocardial infarction: Adverse prognosis for women, particularly for black women. $7 \mathrm{Am}$ Coll Cardio 1987;9:473-82.

7 Greenland P, Reicher-Reiss H, Goldbourt U, Behar S and the Israeli [Aprint Investigators]: In-hospital and 1-year
mortality in 1,524 women after myocardial infarction. mortality in 1,524 women
Circulation 1991;83:484-91.

8 Cowley MJ, Mullin SM, Kelsey SF, Kent KM, Gruentzig $\mathrm{AR}$, Detre $\mathrm{KM}$, et al. Sex differences in early and long term results of coronary angioplasty in the NHLB PTCA Registry. Circulation 1985;71:90-7.

9 Harlan W, Manolio T. Research on coronary disease in women, political or scientific imperative? $\mathrm{Br}$ Heart $\mathscr{f}$ 1993;69:S1-2.

10 Bolooki H, Vargas A, Green R, Kaiser GA, Ghahramani A. Results of direct coronary artery surgery in women. $\mathcal{F}$ Thorac Cardiovasc Surg 1975;69:271-7.

11 Tyras DH, Barner HB, Kaiser GC, Codd JE, Laks H, Willman VL. Myocardial revascularisation in women. Ann Thorac Surg 1978;25:441-53.

12 Fisher LD, Kennedy JW, Davis KB, Maynard C, Fritz JK Kaiser GC, Myers WO and the participating CASS 
Clinics. Association of sex, physical size and operative mortality after coronary artery bypass in Coronary Artery Surgery Study (CASS). $\mathcal{F}$ Thorac Cardiovasc Surg $1982 ; 84: 334-41$.

13 Loop FD, Golding LR, MacMillan JP, Cosgrove DM, Lytle BW, Sheldon WC. Coronary artery surgery in women compared with men: Analysis of risks and long term results. F Am Coll Cardiol 1983;1:383-90.

14 Kennedy JW, Kaiser GC, Fisher LD, Fritz JK, Myers W, Mudd JG, Ryan TJ. Clinical and angiographic predictors of operative mortality. From the collaborative study in coronary artery surgery (CASS). Circulation 1981;63: 793-802.

15 Khan SS, Nessim S, Gray R, Czer LS, Chaux A, Matloff J. Increased mortality of women in coronary artery bypass surgery; evidence of referral bias. Ann Intern Med 1990 112:561-7.

16 Douglas JS Jr., King SB III, Jones EL, Craver JM Bradford JM, Halcher CR Jr. Reduced efficacy of coronary bypass surgery in women. Circulation 1981; 64(suppl II):11-6.

17 O'Connor GT, Plume SK, Olmstead EM, Coffin LH, Morton JR, Maloney CT, Nowicki ER, Tryzelaar JF, Hernandez F, Adrian L, Casy KJ, Soule DN, Marrin CAS, Nugent WC, Charlesworth DC, Clough R, Katz S, Leavitt BJ, Wennberg JE. For the Northern New England Cardiovascular Disease Study Group. regional prospective study of in-hospital mortality asso-
ciated with coronary artery bypass grafting. $\not A M A$ 1991;266:803-9.

18 Weintraub WS, Wenger NK, Jones EL, Craver JM Guyton RA. Changing clinical characteristics of coronary surgery patients. Differences between men and women. Circulation 1993;88(Part 2):79-86.

19 Friedewald WT, Levy RI, Fredrickson DS. Estimation of the concentration of low-density lipoprotein cholesterol in plasma, without use of the preparative ultracentrifuge Clin Chem 1972;18:499-502.

20 Manual of laboratory operation, lipid research clinics program. Lipid and lipoprotein analysis. Vol.I 1974 DHEW Publication No (NIH) 75-628.

21 DuBois D, DuBois EF. Clinical calorimetry: a formula to estimate the appropriate surface area if height and weight to be known. Arch Intern Med 1916;17:863-71.

22 Rogerio A Lobo. Hormones, hormone replacement therapy, and heart disease. In: Douglas PS, eds. Cardiovascular Health and Disease in Women Philadelphia: WB Saunders, 1993:153-73.

23 Armitage P, Berry G. Statistical methods in medical research. Oxford: Blackwell, 1987.

24 Kannel WB. Metabolic risk factors perspective for coronary heart disease in women. From the Framingham nary heart disease in women. From

25 Perlman JA, Wolf PH, Roy R, Lieberknecht G. Cardiovascular risk factors, premature heart disease and all-cause mortality in a cohort of Northern Californi women. Am ₹ Obstet Gynaecol 1988;158:1568-74.
26 Staessen J, Bulpitt CJ, Fagard R, et al. The influence of menopause on blood pressure. $f$ Human Hypertension 1988;3:427-33

27 Kannel WB, McGee DL. Diabetes and glucose tolerance as risk factors for cardiovascular disease. The Framingham Study. Diabetes Care 1979;52:120-6.

28 Manson JE, Colditz GA, Stampfer MJ, et al. A Prospective study of maturity onset diabetes mellitus and risk of coronary heart disease and stroke in women. Arch Intern Med 1991;151:1141-7.

29 Fietsam R Jr, Bassett J, Glover JL. Complications of coronary artery surgery in diabetic patients. Am Surg 1991; 57:551-7.

30 Burgos LG, Ebert TJ, Asiddao C, Turner LA, Pattison CZ, Wang-Cheng R, Kampine J. Increased intraoperative cardiovascular morbidity in diabetics with autonomic neuropathy. Anesthesiology 1989;70:591-7.

31 Mann J, Doll R, Thorogood M, Vessey MP, Waters WE. Risk factors for myocardial infarction in young women. Br f Soc Med 1976;30:94-100.

32 Castelli WP, Garrison RJ, Wilson PWF, Abott RD, Kalousdian S, Kannel WBC. Incidence of coronary heart disease and lipoprotein cholesterol levels. The Framingham Study. $\mathscr{f} A M A$ 1986;256:2835-8.

33 Lapidus L, Bengtsson C, Linqquist $O$, Sigurdsson JA, Rybo E. Triglycerides: main risk for cardiovascular disease in women. Acta Med Scand 1985;217:481-9.

34 Castelli WP. The triglyceride issue. A view from Framingham. Am Heart $₹$ 1986;112:432-7.

35 Ornish D, Brown SE, Scherwitz LW, et al. Can life style changes reverse coronary heart disease? Lancet 1990; 336:129-33.

36 Kane JP, Malloy MJ, Ports TA, et al. Regression of coronary atherosclerosis during treatment of familial hypercholesterolemia with combined drug regimens. $\mathscr{f} A M A$ 1990;264:3007-12.

37 O'Connor GT, Morton JR, Diehl MJ, Olmestead EM, Coffin LH, Levy DG, et al. Differences Between Men and Women in Hospital Mortality Associated with Coronary Artery Bypass Graft Surgery. Circulation 1993;88 (part 1):2104-10).

38 Lytle BW, Loop FD, Cosgrove DM, Ratliff NB, Easley K, Taylor PC. Long term (5 to 12 years) serial studies of internal mammary artery and saphenous vein coronary artery bypass grafts. $\mathcal{F}$ Thorac Cardiovasc Surg 1985;89: 248-58.

39 Grondin CM, Campeau L, Lesperance J, Enjalbert M, Bourassa MG. Comparison of late changes in internal mammary artery and saphenous vein grafts in two consecutive series of patients 10 years after operation. Circulation 1984;70(suppl I):1208-12.

40 Okies JE, Page US, Bigelow JV, Krause AH, Salmon NW. The left internal mammary artery: the graft of choice. Circulation 1984;70(suppl I):213-21.

41 Green GE. Internal mammary artery-to-coronary artery anastomosis: Three years experience with 165 patients. Ann Thorac Surg 1972;14:260-71. 